\title{
The Effects of Warm Air Heater on the Dispersion and Deposition of Particles in an Enclosed Environment
}

\author{
Xi Chen ${ }^{1,2^{*}}$, Jiangyi $\mathrm{Li}^{1}$, Xiangxiang Zhang ${ }^{1}$, Shuai Liu ${ }^{1}$, Kapnang Franky ${ }^{1}$, \\ Wanwan $\mathrm{Li}^{1}$, Wenfeng $\mathrm{Bi}^{1}$ \\ ${ }^{1}$ School of Civil Engineering and Architecture, Henan University of Technology, Zhengzhou \\ 450001, Henan, China \\ ${ }^{2}$ Key Laboratory of Heating and Air Conditioning, The Education Department of Henan Province, \\ Zhengzhou 450007, Henan, China
}

\section{ABSTRACT}

Warm air heaters are now widely used in enclosed environments, either as primary or auxiliary heating facilities. However, the influence of these heaters on the indoor air quality has received scant attention, and the currently available data is insufficient. Therefore, this study experimentally investigated the particle concentrations, air velocity, temperature, and relative humidity in a storeroom equipped with a warm air heater. To assess the effects of the heater on the dispersion and deposition of $0.3,0.5,1.0,3.0$, and $5.0 \mu \mathrm{m}$ particles, we analyzed 18 scenarios with various settings for the output power and outlet orientation. The results indicated higher particle deposition rates when the heater was operating. Furthermore, the particles' decay rate loss coefficients increased with the heater's output power and the particles' proximity to the heater's air outlet but were also influenced by the direction of the warm air flow.

Keywords: Particle concentration, Warm air heater, Particle decay rate loss coefficient, Particle dispersion, Particle deposition

\section{OPEN ACCESS}

\section{INTRODUCTION}

Received: November 5, 2020

Revised: February 10, 2021

Accepted: March 10, 2021

\section{${ }^{*}$ Corresponding Author: \\ chenxiilmmvm@126.com}

\section{Publisher:}

Taiwan Association for Aerosol Research

ISSN: $1680-8584$ print ISSN: 2071-1409 online

cc) Copyright: The Author(s). This is an open access article distributed under the terms of the Creative Commons Attribution License (CC BY 4.0), which permits unrestricted use, distribution, and reproduction in any medium, provided the original author and source are cited.

People spend most of their time indoors and consequently indoor air quality is very vital to human health (Robinson and Nelson, 1995). Exposure to the suspended particles in indoor environments contributes to people's health risks and has caused widespread concern (Cao et al., 2017). Airborne particles can be suspended over a long time and travel over long distances in the atmosphere and have adverse effects on human health. A lot of scientific studies have proved that particle exposure can cause many diseases, which include heart or lung disease, aggravated asthma, and increased respiratory symptoms (Fang et al., 2013; Kim et al., 2015). The data collected from 652 cities in 24 countries or regions shows that an increase of $10 \mu \mathrm{g} \mathrm{m}^{-3}$ in $\mathrm{PM}_{10}$ concentration is relevant to an increase of $0.36 \%$ in daily cardiovascular mortality and an increase of $0.47 \%$ in daily respiratory mortality. The study also exhibits an increase of $10 \mu \mathrm{g} \mathrm{m}^{-3}$ in the 2day moving average of $\mathrm{PM}_{10}$ and $\mathrm{PM}_{2.5}$ concentrations are associated with increases of $0.44 \%$ and $0.68 \%$ in daily all-cause mortality, respectively (Liu et al., 2019). Therefore, exposure to the suspended particles indoors is an important area in which researches should be taken.

China has been suffering from severe haze episodes that sweep across Chinese cities in recent years, especially during the winter heating season (Xu et al., 2017; Cheng et al., 2019).

Many studies have been published reporting high values of $\mathrm{PM}_{2.5}$ concentration during the winter in some Chinese cities such as Beijing, Tianjin, Shijiazhuang, Handan, Changzhou, Wuhan, and Zhengzhou (Li et al., 2017; Qin et al., 2017; Shao et al., 2018; Yang et al., 2018; Jin et al., 2019; Ye et al., 2019; Dong et al., 2020). It appears that many cities in China have been suffering serious 
haze pollutions during wintertime. Therefore, due to the higher level of particulate matter concentration in winter, it is essential to pay close attention to the indoor particles during the heating season, besides the thermal comfort.

The influence of indoor heating systems on the airborne particle dispersion and deposition has been extensively studied over the last few years. The contribution of different heating systems such as electric baseboard heaters, natural gas furnace, hot water heaters, and wood stoves to indoor particle exposures were discussed (Silberstein, 1979; Moriske et al., 1996; Spolnik et al., 2007; Weichenthal et al., 2007; Ozgen et al., 2012). For instance, Golkarfard and Talebizadeh (2014) analyzed the deposition and dispersion of airborne particles in two radiator and floor heating systems. Results showed that the deposition ratio of particles was higher in the radiator heating system than in the floor heating system. The effect of radiators on particle size distributions and concentrations was evaluated by Chen and $\mathrm{Li}$ (2015). It was found that the environmental parameters (particle concentrations in the adjacent indoor air, temperatures, relative humidity, and air velocities) were related to the particle concentrations above radiators with various degrees. Moreover, Zhou et al. (2017) studied the particle dispersion in a ventilated and floor-heated indoor environment by using experimental measurements and computational fluid dynamics methods, noting that the higher the inlet velocity, the faster particle concentration decayed. The particulate matter in the indoor atmosphere of two flats where airtight biomass systems were used for domestic heating was measured by Frasca et al. (2018). The results confirmed that biomass-fueled heating systems are a significant source of the indoor pollution. In the same year, Stabile et al. (2018) explored the exposure to different airborne particle metrics (including both sub- and supermicron particles) and attached carcinogenic compounds in dwellings where three different heating systems were used: open fireplaces, closed fireplaces and pellet stoves. The results demonstrated that the most probable surface area extra-doses received by people exposed to open fireplaces on hourly basis resulted one order of magnitude larger than those experienced for exposure to closed fireplaces and pellet stoves. Also, Dehghan and Abdolzadeh (2018) compared the air flow and particle dispersion in a room with three heating systems: floor heating, skirt boarding heating, and radiator heating systems, indicating that the skirt boarding heating system had the lowest particle concentration in the breathing zone of the manikin.

Based on the reviewed literature above, the results indicate that some specific factors caused by heating systems such as the rising temperature and the hot airflow have an impact on particle dispersion and deposition, and then influence the indoor air quality. Also, the difference in the conditions of the particle motion among indoor environments with different heating systems is quite significant. Many heating systems such as the radiator, floor, and biomass-fueled heating system have been extensively studied. However, the effect of warm air heaters, which can supply heated air from the outlet at a certain velocity, on particulates in enclosed spaces has received scant attention with insufficient available data. The warm air heaters have been widely applied in indoor environments without central heating systems or served as auxiliary heating facilities. The condition of particles in enclosed environments using warm air heaters is not yet fully known. Moreover, few studies have looked at the influence of user's habits of warm air heaters on indoor air quality. It seems that the warm air heaters are still needed to study further in order to check out their effects on indoor particles as well as the related influencing factors in enclosed spaces. Then the results can be used in the contamination control and the improvement of indoor air quality.

The purpose of this work is to experimentally probe the influence of a warm air heater with different output powers on distributions of particulates (ranging from 0.3 to $5.0 \mu \mathrm{m}$ ) and the deposition in a room-sized enclosure. The particle concentrations, air velocities, temperatures, and relative humidity were measured simultaneously at the same sampling point under 18 test conditions. Moreover, we calculated the particle decay rate loss coefficients to estimate the influence of air outlet orientation as well as the distance from the warm air heater on indoor particle loss. This study is expected to facilitate the improvement of indoor air quality for using warm air heaters during the heating period in winter. 


\section{METHODS}

\subsection{Experimental Set-up}

\subsubsection{Site description}

To analyze the effect of warm air heaters on indoor particle dispersion and deposition, measurements are conducted in an environmentally controlled residential storeroom in Zhengzhou, China. This storeroom used for performing the heating activities is a semi-basement in a six-floor building and far from streets. The size of the storeroom is $3300 \mathrm{~mm}(\mathrm{~L}) \times 2370 \mathrm{~mm}(\mathrm{~W}) \times 2240 \mathrm{~mm}$ $(\mathrm{H})$ as shown in Fig. 1(a). An exterior window with the dimension of $1670 \mathrm{~mm}(\mathrm{~W}) \times 250 \mathrm{~mm}(\mathrm{H})$ locates in the north wall. An interior door of dimension $650 \mathrm{~mm}(\mathrm{~W}) \times 2000 \mathrm{~mm}(\mathrm{H})$ locates in

(a)

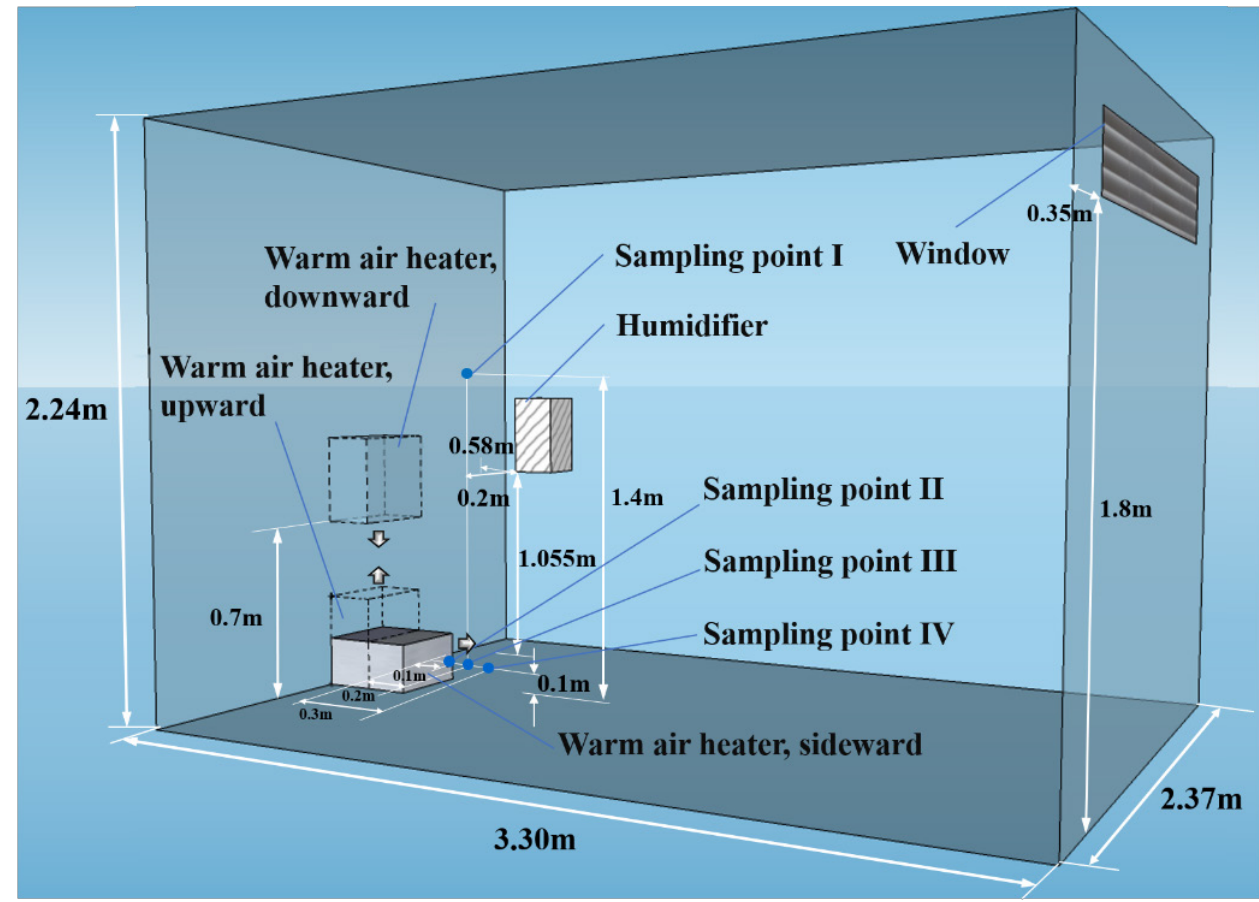

(b)

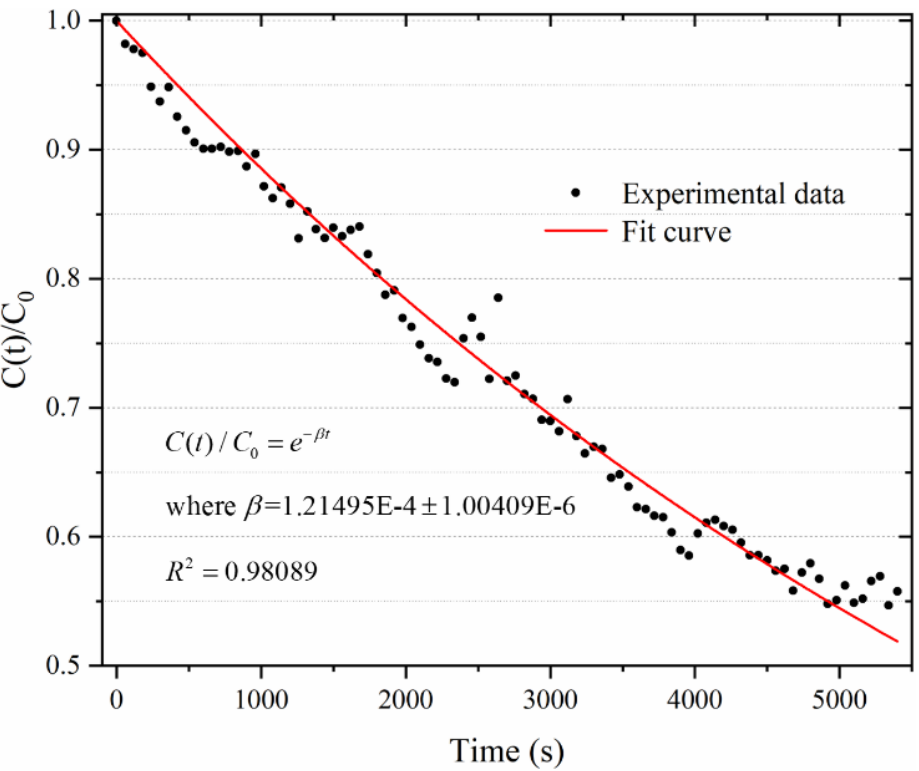

Fig. 1. (a) Schematic of the storeroom. (b) Extracted plot of particle concentration decay and negative slope of the regression curve. The presented data is extracted from data series of $0.3 \mu \mathrm{m}$ particles measured in Case 10. 
the east wall. There is an electrical warm air heater (Model HP20013-W) of dimension $355 \mathrm{~mm}$ (L) $\times$ $380 \mathrm{~mm}(\mathrm{~W}) \times 200 \mathrm{~mm}(\mathrm{H})$ with three levels of output powers, which is placed next to the interior south wall. A portable ultrasonic humidifier (Model JSQ-A50M2), which owns the rated humidification capacity of $280-380 \mathrm{~mL} \mathrm{~h}^{-1}$, is installed at the height of $1055 \mathrm{~mm}$ above the floor. More details of the locations of these facilities can be seen in Fig. 1(a).

\subsubsection{Apparatus and parameters measured}

Measurements of concentrations of $0.3,0.5,1.0,3.0$, and $5.0 \mu \mathrm{m}$ particles are conducted with a Kanomax Handheld Laser Particle Counter (Model 3886 GEO- $\alpha$ ). This instrument has been built for continuous measurement of airborne particle concentrations and meets FED-STD-209E, ISO14644-1, and other relevant environmental standards. Some researchers have employed the Handheld Laser Particle Counter to sample particles and obtained relatively accurate data (Xiong et al., 2015; Hasan et al., 2016). The main parameters of this Kanomax Handheld Laser Particle Counter are displayed in Table 1.

The temperature and relative humidity are monitored along with the particle concentrations by TSI IAQ-Calc Indoor Air Quality Meter (Model 7545), which is widely accepted by researchers (Meišutovič-Akhtarieva et al., 2019; Seduikyte et al., 2019). A TSI Air Velocity Meter (Model 9555) is selected for monitoring the air velocity at sampling points during the heating procedures. The TSI 9555 Air Velocity Meter has been used in the field of indoor measurements by several authors (Chaivisit et al., 2018; Dunn et al., 2020). More information on the TSI 7545 IAQ-Calc Indoor Air Quality Meter and TSI 9555 Air Velocity Meter can be seen in Table 1.

\subsection{Studied Cases}

To explore the particle dispersion and deposition during the heating period, 18 cases with different heating powers of the warm air heater are studied. The details of these 18 cases are listed in Table 2. The air blowing directions, which are caused by placement modes of the warm air heater and related to the user's habits, are also considered in this work. Three common air blowing directions, those called upward, sideward, and downward, are chosen to be discussed. Besides, using a humidifier to add moisture is a choice for some people during the heating season. For a better understanding of the effects of the humidifier with tap water on the particle concentration, the on-off patterns of a humidifier with the fixed humidification capacity of $330 \mathrm{~mL} \mathrm{~h}^{-1}$ are set in different cases. A total of four sampling points are set in this experiment. Among them, three sampling points are near the air outlet of the warm air heater and one other point is located in the breathing zone. Sampling Points II-IV with different distances from the air outlet of the warm air heater are set. Sampling Point II is $0.1 \mathrm{~m}$ from the air outlet of the warm air heater. The gaps between Sampling Points II and III as well as Sampling Points III and IV are both set as $0.1 \mathrm{~m}$ (Fig. 1(a)). Sampling Points II-IV are all in the centerline of the air outlet of the warm air heater and the positions change with the air blowing directions. Sampling Point I, which locates in the adjacent indoor air, is $1.3 \mathrm{~m}$ above Sampling Point II in cases with the sideward warm air heater, as shown in Fig. 1(a).

Table 1. The main parameters of instruments.

\begin{tabular}{|c|c|c|}
\hline Names of instruments & Performance Parameters & Measured Parameters \\
\hline \multirow{2}{*}{$\begin{array}{l}\text { Kanomax Handy Laser Particle } \\
\text { Counter (Model 3886GEO- } \alpha \text { ) }\end{array}$} & Particle size: $0.3,0.5,1.0,3.0,5.0 \mu \mathrm{m}$ & \multirow{2}{*}{$\begin{array}{l}\text { Concentrations of } 0.3 \mu \mathrm{m} \text {, } \\
0.5 \mu \mathrm{m}, 1 \mu \mathrm{m}, 3 \mu \mathrm{m} \text { and } \\
5 \mu \mathrm{m}\end{array}$} \\
\hline & $\begin{array}{l}\text { Particle concentration: } 1-2000000 \text { particles } \mathrm{cf}^{-1} \\
\text { Reproducibility: } \pm 5 \% \text { over the whole measuring range }\end{array}$ & \\
\hline \multirow[t]{2}{*}{$\begin{array}{l}\text { TSI } 7545 \text { IAQ-Calc Indoor Air } \\
\text { Quality Meter }\end{array}$} & $\begin{array}{l}\text { Air temperature range: } 0-60^{\circ} \mathrm{C} \text { (Accuracy: } \pm 0.6^{\circ} \mathrm{C}, \\
\quad \text { Resolution: } 0.1^{\circ} \mathrm{C} \text { ) }\end{array}$ & \multirow[t]{2}{*}{$\begin{array}{l}\text { Temperature and relative } \\
\text { humidity }\end{array}$} \\
\hline & $\begin{array}{l}\text { Relative humidity range: } 5-95 \% \mathrm{RH} \text { (Accuracy: } \pm 3 \% \mathrm{RH} \text {, } \\
\text { Resolution: } 0.1 \% \mathrm{RH} \text { ) }\end{array}$ & \\
\hline \multirow[t]{2}{*}{ TSI 9555 Air Velocity Meter } & Range: 0 to $9999 \mathrm{ft} \min ^{-1}\left(0-50 \mathrm{~m} \mathrm{~s}^{-1}\right)$ & \multirow[t]{2}{*}{ Air velocity } \\
\hline & $\begin{array}{l}\text { Accuracy: } \pm 3 \% \text { of reading or } \pm 3 \% \mathrm{ft} \min ^{-1}\left( \pm 0.015 \mathrm{~m} \mathrm{~s}^{-1}\right) \text {, } \\
\text { whichever is greater } \\
\text { Resolution: } 1 \mathrm{ft} \min ^{-1}\left(0.01 \mathrm{~m} \mathrm{~s}^{-1}\right)\end{array}$ & \\
\hline
\end{tabular}


Table 2. The experimental cases.

\begin{tabular}{llllllll}
\hline Case & $\begin{array}{l}\text { Sampling } \\
\text { point }\end{array}$ & $\begin{array}{l}\text { Heating } \\
\text { power }(\mathrm{W})\end{array}$ & $\begin{array}{l}\text { Air blowing } \\
\text { direction }\end{array}$ & Humidifier & $\begin{array}{l}\text { Average air } \\
\text { velocity }\left(\mathrm{m} \mathrm{s}^{-1}\right)\end{array}$ & $\begin{array}{l}\text { Temperature } \\
\text { rise }\left({ }^{\circ} \mathrm{C}\right)\end{array}$ & $\begin{array}{l}\text { Relative humidity } \\
\text { drop }(\%)\end{array}$ \\
\hline 1 & I & Off & Upward & Off & 0.000 & +0.5 & +0.1 \\
2 & I & 2000 & Upward & Off & 0.000 & +2.9 & +0.3 \\
3 & I & 2000 & Upward & On & 0.000 & +2.1 & -35.4 \\
4 & II & 800 & Upward & Off & 1.321 & +6.3 & +1.9 \\
5 & II & 1200 & Upward & Off & 1.335 & +7.3 & +2.5 \\
6 & II & 2000 & Upward & Off & 1.371 & +9.9 & +4.0 \\
7 & II & 800 & Sideward & Off & 1.838 & +8.5 & +2.9 \\
8 & II & 1200 & Sideward & Off & 1.850 & +36.5 & +12.3 \\
9 & II & 2000 & Sideward & Off & 1.942 & +41.4 & +14.3 \\
10 & II & 800 & Downward & Off & 1.377 & +14.7 & +5.8 \\
11 & II & 1200 & Downward & Off & 1.395 & +38.7 & +12.4 \\
12 & II & 2000 & Downward & Off & 1.624 & +42.4 & +19.3 \\
13 & III & 1200 & Upward & Off & 1.138 & +4.1 & +0.9 \\
14 & IV & 1200 & Upward & Off & 0.804 & +3.5 & +0.6 \\
15 & III & 1200 & Sideward & Off & 1.817 & +31.5 & +9.3 \\
16 & IV & 1200 & Sideward & Off & 1.169 & +30.2 & +8.9 \\
17 & III & 1200 & Downward & Off & 1.166 & +34.5 & +12.1 \\
18 & IV & 1200 & Downward & Off & 1.028 & +32.2 & +10.1 \\
\hline
\end{tabular}

\subsection{Experimental Procedure}

In this work, when preparations are completed, the warm air heater, Kanomax Handheld Laser Particle Counter, TSI 7545 IAQ-Calc Indoor Air Quality Meter, and TSI 9555 Air Velocity Meter start running and the operator leaves the storeroom. In Case 3, the humidifier is turned on at the same time. To minimize the human impact, the level of operator activities is kept low and the data of the first 1 minute is eliminated from the data sets. The sampling instruments are alternatively positioned at each sampling point and the parameters are continuously measured for 90 minutes (5400 seconds). The logging interval of the Kanomax Handheld Laser Particle Counter is set to 60 seconds, which means the particle concentrations are automatically recorded every 1 minute. During the measurements, the temperature, relative humidity, and air velocity are automatically recorded every 1 second. The average air velocity over the 90 minutes serves as the data used in the later analysis.

The interior door and the exterior window are opened for at least 2 hours to keep the air fresh in the room before each measurement. This period is used to ensure the current measurement is not affected by the preceding one. There is no specific particle source used in this experiment. The initial particle concentrations in different cases are not same and in the range of 111,993334,240 particles $\mathrm{m}^{-3}$ for $0.3 \mu \mathrm{m}$ particles, $7556-75,291$ particles $\mathrm{m}^{-3}$ for $0.5 \mu \mathrm{m}$ particles, $2103-$ 60,622 particles $\mathrm{m}^{-3}$ for $1.0 \mu \mathrm{m}$ particles, $521-4378$ particles $\mathrm{m}^{-3}$ for $3.0 \mu \mathrm{m}$ particles and $153-$ 1046 particles $\mathrm{m}^{-3}$ for $5.0 \mu \mathrm{m}$ particles. The door and the window are closed in the monitoring process to minimize the effect of the outdoor air and particle penetration. During the tests, the storeroom is unoccupied and without mechanical ventilation. In order to reduce errors, the experiments are at least repeated twice for each case. A minimum of six measurements have been conducted for each factor, i.e., a minimum of twice repeats for each of the three different heating powers.

\subsection{Definition of Some Parameters}

\section{4.1 Definition of particle decay rate loss coefficient}

In this paper, the particle decay rate loss coefficient, which is most commonly studied to judge the particle loss in an enclosure, is used to compare the particle deposition in different cases. Since the room is well sealed and the particle concentration is relatively low, the coagulation, evaporation, condensation, and infiltration of particles are ignored. The particle decay rate loss coefficient in a well-mixed room can be obtained according to the following formula (Chen and 
Li, 2014; Wang et al., 2018):

$C(t)=C_{0} \exp (-\beta t)$

where $C(t)$ describes the indoor particle concentration (particles $\mathrm{m}^{-3}$ ), $C_{0}$ represents the initial concentration (particles $\mathrm{m}^{-3}$ ), $\beta$ is the particle decay rate loss coefficient $\left(\mathrm{s}^{-1}\right)$ and $t$ is the elapsed time (s).

In this study, $\beta$ is calculated by fitting the decay curve of the dimensionless concentrations $\left(C(t) / C_{0}\right)$. As an illustration, Fig. 1(b) illustrates the exponential decay of particle concentration for the $0.3 \mu \mathrm{m}$ particles in Case 10.

\subsubsection{Definition of temperature rise and relative humidity drop}

In order to assess the influence of the temperature and the relative humidity on indoor particle concentrations, the temperature rise and relative humidity drop are introduced in this study.

The temperature rise and relative humidity drop, which are expected to reduce the effect of corresponding initial parameter difference on the results, are estimated by the following equations:

$\Delta t=\bar{t}_{1}-\bar{t}_{2}$

$\Delta \varphi=\overline{\varphi_{1}}-\overline{\varphi_{2}}$

where $\Delta t$ and $\Delta \varphi$ are the temperature rise $\left({ }^{\circ} \mathrm{C}\right)$ and relative humidity drop (\%), respectively, $\bar{t}_{1}$ and $\overline{\varphi_{1}}$ represent the average temperature and relative humidity of the first 60 seconds in the measurement, respectively, $\bar{t}_{2}$ and $\overline{\varphi_{2}}$ are the average temperature and relative humidity of the last 60 seconds in the measurement, respectively.

The temperature rise and relative humidity drop in different cases are summarized in Table 2. The temperature rise and relative humidity drop at the sampling point in this experiment may be affected by the heating powers, the distance from the air outlet and air blowing directions. From Table 2, it can be concluded that the temperature rise increases with rising heating powers of the warm air heater and decreases as the distance from the air outlet is increased. For most cases, there is a positive correlation between the temperature rise and relative humidity drop.

\section{RESULTS AND DISCUSSION}

\subsection{Comparison of the Suspended Particles in the Enclosed Environment with Idle and Working Warm Air Heater and Humidifier}

The particle dimensionless concentrations at Sampling Point I against time in Cases 1-2 are presented for comparison (Fig. 2). With a similar trend to those in the case with the idle warm air heater (Case 1), the particle dimensionless concentrations decrease as the elapsed time increases in Case 2. The loss of indoor particles is mainly due to the particle deposition in the absence of indoor and outdoor particle sources. In addition, it can be seen in Fig. 2 that the particle dimensionless concentrations in Cases 1 and 2 decline faster initially and then tend to be gentle. It also indicates that the dimensionless concentrations of larger particles have a much higher dropping rate comparing to the smaller particles. The possible cause is that larger particles have greater mass and the gravitational settling serves as the dominant factor on the particulate deposition. Comparing the data in Cases 1 and 2, one finds that the slope of particle dimensionless concentrations curve in Case 2 is observed to be greater than that in Case 1 during the measurement. And the particle dimensionless concentrations curves of larger particles $(1.0,3.0$, and $5.0 \mu \mathrm{m})$ for the two cases are relatively close. Part of the reason for this difference might be due to the greater effects of thermophoresis and airflow fields on smaller particles. The thermophoretic force, which has the direction opposite to the temperature gradient, can enhance smaller particles' deposition on cold walls. It is evident that the temperature rise in Case 2 is larger than that in Case 1. Also, smaller particles with relatively little inertia are more susceptible to airflows. From Fig. 2 , it is also noted that the dimensionless concentration of $5.0 \mu \mathrm{m}$ particles has a larger fluctuation than that of 
(a)

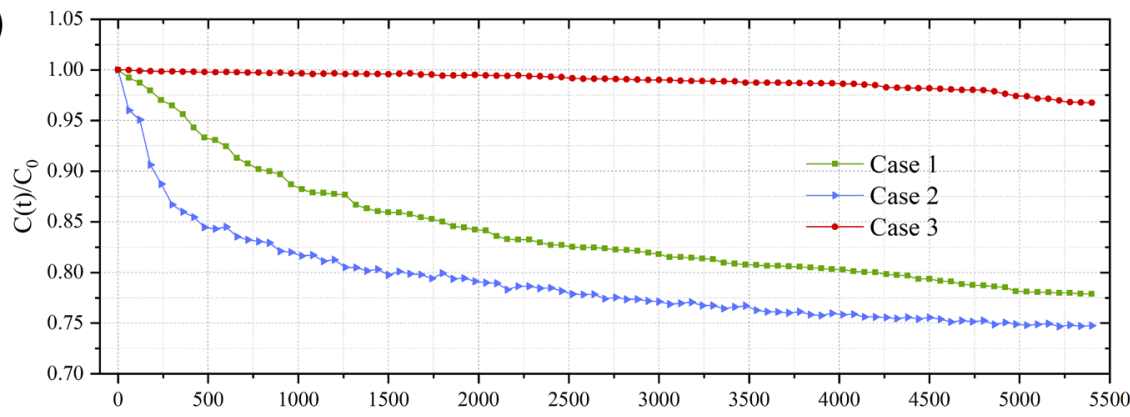

(b)

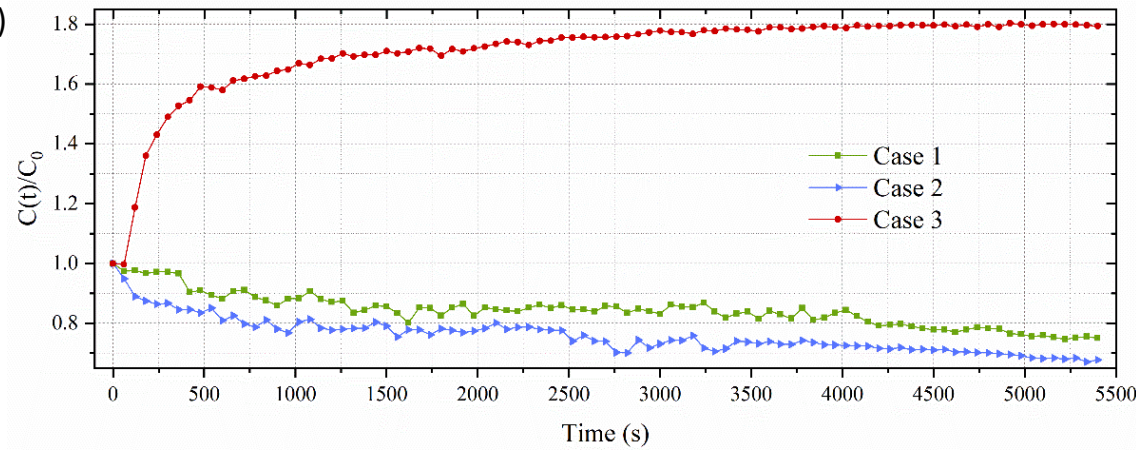

(c)

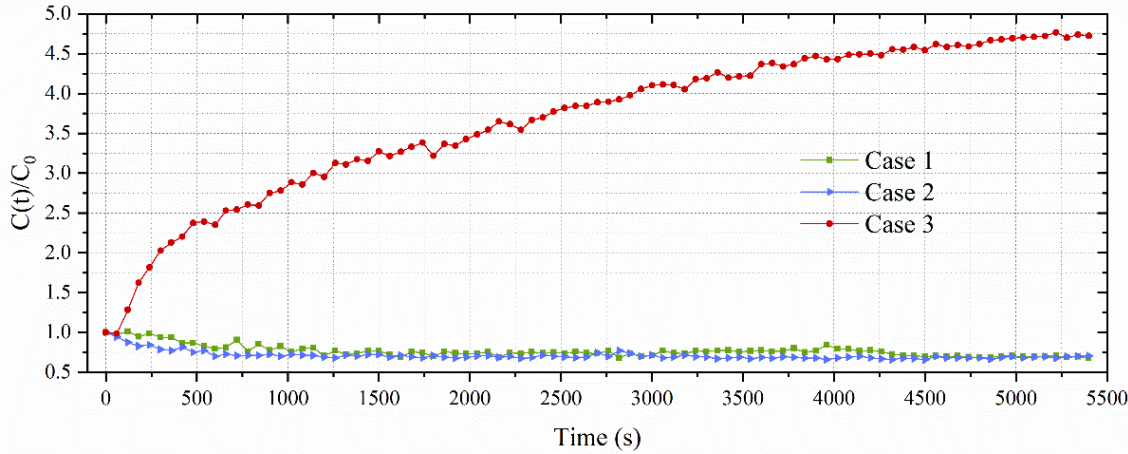

(d)

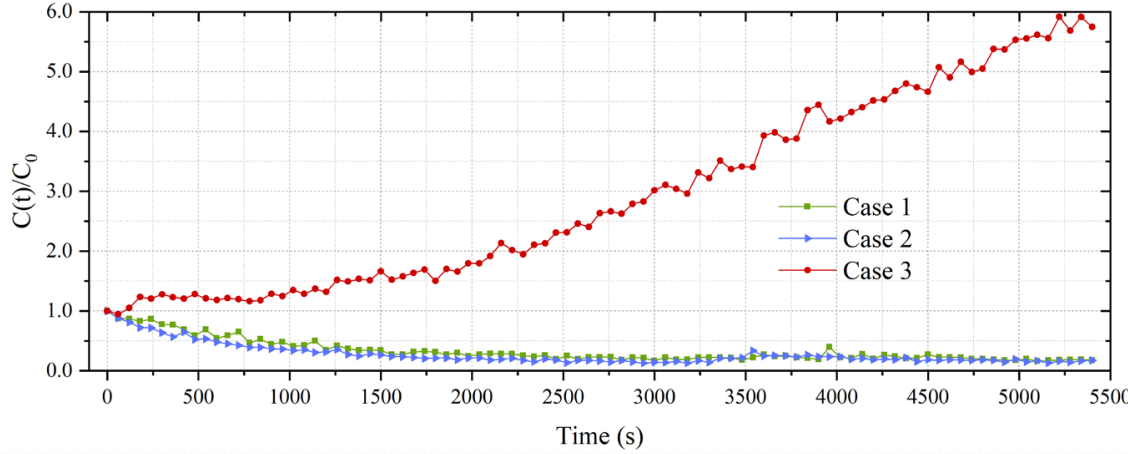

(e)

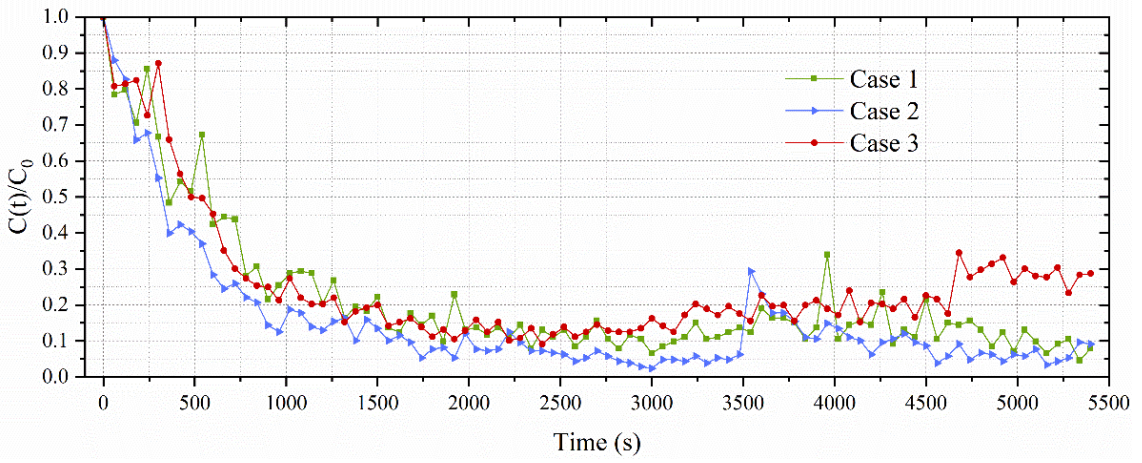

Fig. 2. The dimensionless concentrations of (a) $0.3 \mu \mathrm{m}$, (b) $0.5 \mu \mathrm{m}$, (c) $1.0 \mu \mathrm{m}$, (d) $3.0 \mu \mathrm{m}$, and (e) $5.0 \mu \mathrm{m}$ particles at Sampling Point I against time in Cases 1-3. 
other particles. This may be attributed to the fewer large particles in the indoor environment and to the fact that the initial quantity of large particles is smaller. The air may make some large particles resuspended and the resuspended particles are likely to be deposited onto surfaces again.

Also, in Fig. 2, we compare the $C(t) / C_{0}$ in Cases 2 and 3 under the conditions of idle and working humidifier. For all of results presented, it is noted that the particles' dimensionless concentration in Case 3 appears to be larger than that in Case 2 for most of the data sets. The result may prove that the use of a humidifier with tap water leads to a growth of particle concentrations, consistent with some conclusions presented previously (Zhao, 2018). The portable ultrasonic humidifier generates the vapor, water droplets, and particles due to the mineral composition dissolved in tap water, which may be resulting in the rise of the relative humidity and particle concentrations. Comparing the patterns in Figs. 2(a), 2(b), 2(c), 2(d) and 2(e), the dimensionless concentrations of $0.5,1.0$ and $3.0 \mu \mathrm{m}$ particles in Case 3 increase sharply. After the first 90 minutes, the concentrations of $0.5,1.0$, and $3.0 \mu \mathrm{m}$ particles in Case 3 increase to $179.32 \%, 472.58 \%$, and $574.58 \%$ of the initial background values, respectively, whereas the ratios of 0.3 and $5.0 \mu \mathrm{m}$ particle concentrations decrease to $96.74 \%$ and $28.72 \%$, respectively. The maximum dimensionless concentrations in Case 3 for 0.5, 1.0 and $3.0 \mu \mathrm{m}$ particles ordered from high to low are $3.0 \mu \mathrm{m}$, then $1.0 \mu \mathrm{m}$, and $0.5 \mu \mathrm{m}$. A possible cause is that the ultrasonic humidifier releases particles with specific sizes. Moreover, the water droplets will capture some particles by diffusion, impaction, and interception effects and particles will absorb water vapor (Feng et al., 2018), which makes the particle size increase. Otherwise, as gravitational settling velocity increases to the square of the particle diameter, the gravitational settling is the dominant force on particle deposition when the particle sizes are large enough. The dimensionless concentrations of 0.3 and $5.0 \mu \mathrm{m}$ particles are no more than 1 during the measurement period may since they are too small or too large.

\subsection{Effect of the Working Warm Air Heater on Particles with Different Sizes}

The particle size is an important factor that influences particulate motions. To explore the effect of the working warm air heater on particles with different sizes, the dimensionless concentrations of $0.3,0.5,1.0,3.0$, and $5.0 \mu \mathrm{m}$ particles in Case 11 are plotted in Fig. 3. From Fig. 3, it can be concluded that the dimensionless concentrations of particles with different sizes all decrease with increasing elapsed time. The larger the particle size is, the faster the particles settle. The discrepancy may be due to the greater gravity of larger particles. Also, it can be seen in Fig. 3 that the dimensionless concentrations of 3.0 and $5.0 \mu \mathrm{m}$ particles are volatile. The results also indicate that the $C(t) / C_{0}$ of larger particles declines more sharply in the first 500 seconds. These findings are consistent with some results reported by other researchers (Chen and Li, 2014). The smaller initial numbers of larger particles and the effect of the airflow possibly trigger this result.

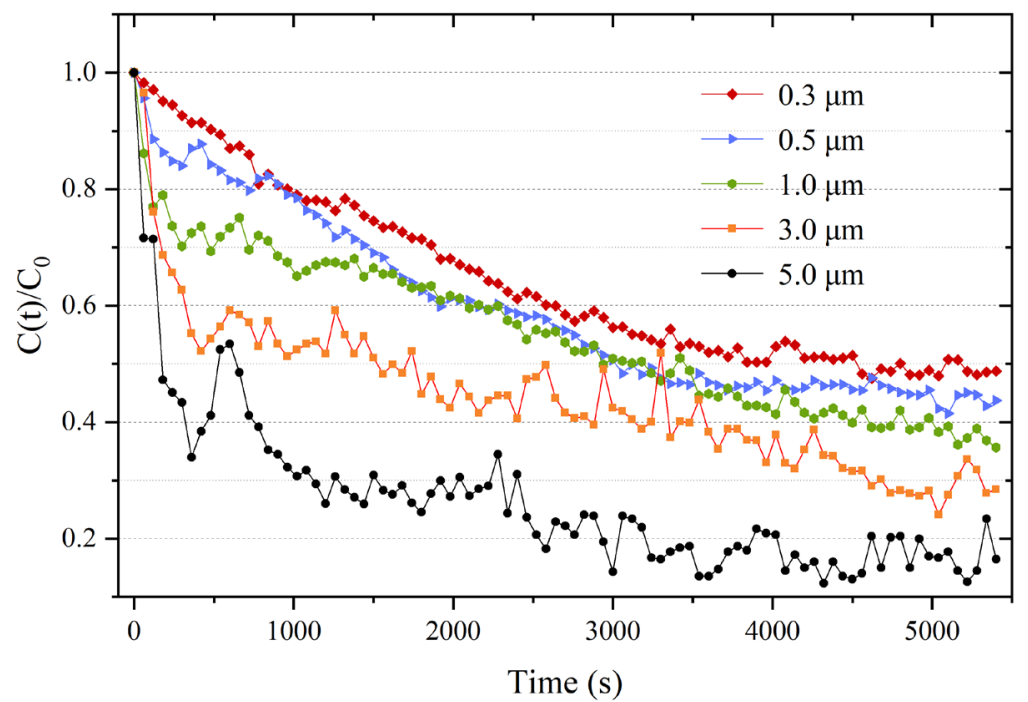

Fig. 3. Comparison of dimensionless concentrations of $0.3,0.5,1.0,3.0$, and $5.0 \mu \mathrm{m}$ particles against time under Case 11. 
To uncover more about the influences of the warm air heater on particles, the dimensionless concentrations of 0.3 and $5.0 \mu \mathrm{m}$ particulates in cases with different output powers of the warm air heater (Cases 10, 11, and 12) are given in Fig. 4. In Cases 10-12, the result shows that the dropping rate of particle dimensionless concentrations increases with the rising output powers of the warm air heater, especially for smaller particulates $(0.3 \mu \mathrm{m})$. With a similar pattern to the dropping rate of particle dimensionless concentrations, it is recognized from Table 2 that the average air velocity, temperature rise, and relative humidity drop tend to increase as the output powers of warm air heater is increased. The possible reason for the result of particle concentrations is the effect of thermophoretic force and the turbulent intensity. The enhancement of thermophoretic force in cases with greater output power increases the particulate deposition, which triggers a decrease in the concentration of suspended particulates. At the same time, the strengthening of the airflow may result in the growth of the particle deposition. Comparing the dimensionless concentrations in Figs. 4(a) and 4(b), one finds that the fluctuation in the concentration of $5.0 \mu \mathrm{m}$ particles is much greater than that in the concentration of $0.3 \mu \mathrm{m}$ particles. Besides, the dimensionless concentration curves of $5.0 \mu \mathrm{m}$ in the three cases are closer to each other. The greater influences of the thermophoresis and airflow on smaller particles may cause this difference in the results for 0.3 and $5.0 \mu \mathrm{m}$ particles.

(a)

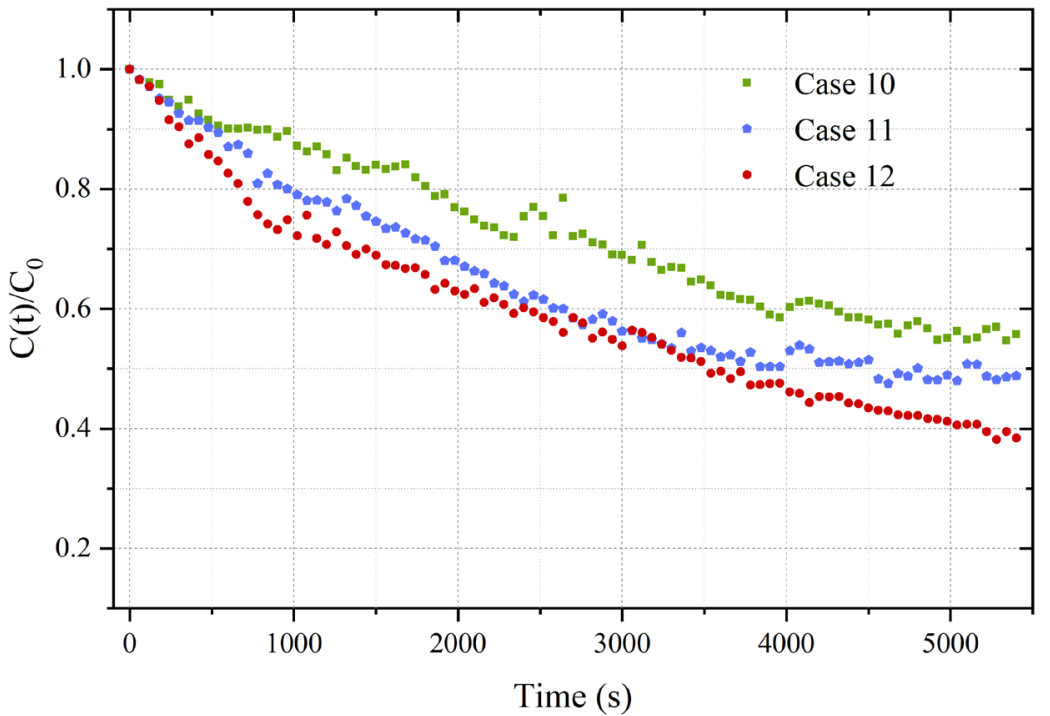

(b)

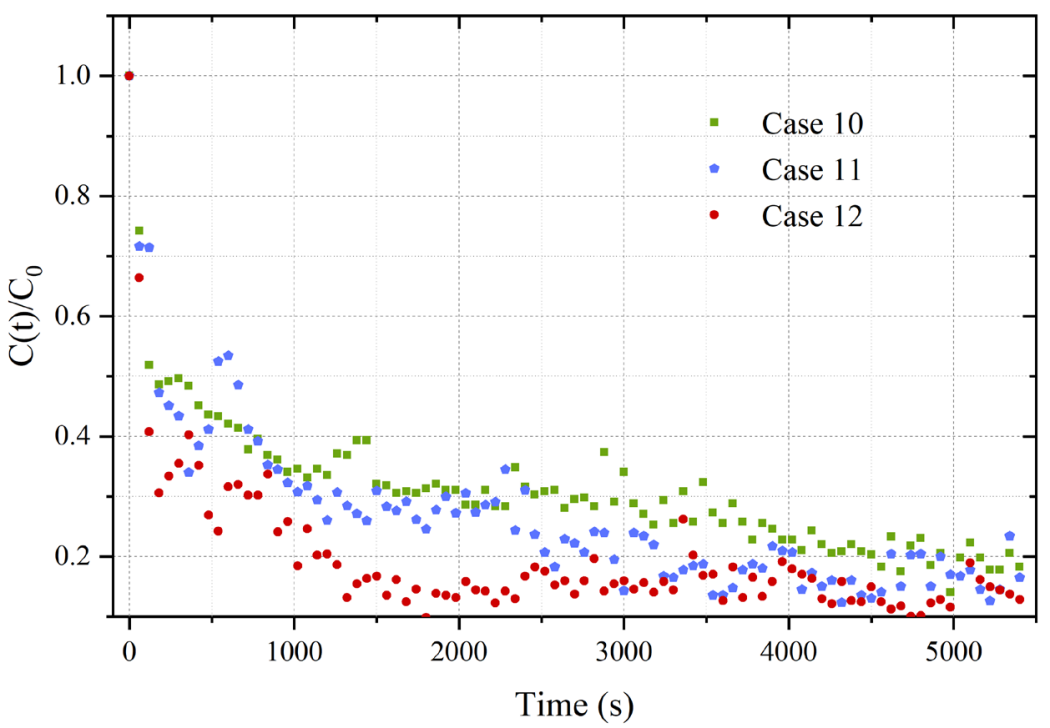

Fig. 4. Effect of output power of the warm air heater with the downward air blowing direction on particle dimensionless concentrations at Sampling Point II: (a) $0.3 \mu \mathrm{m}$ and (b) $5.0 \mu \mathrm{m}$ particles. 


\subsection{Effect of the Air Outlet Orientation on Particles}

Fig. 5 compares the particle decay rate loss coefficients in cases with different air outlet orientations. According to the results, the larger the output power of warm air heater, the greater the particle decay rate loss coefficient. It is also seen that the particle decay rate loss coefficients in cases with the upward airflow are lowest for most particle sizes while keeping the output power of the warm air heater constant. This relative relationship is similar to the velocity, temperature rise, and relative humidity drop patterns. The reductions of the thermophoretic force and the air velocities may lead to lower particle decay rate loss coefficients in cases with the upward airflow. As shown in Fig. 5, the decay rate loss coefficients in cases with downward airflow are slightly higher than that in cases with sideward airflow for $0.3,0.5$, and $1.0 \mu \mathrm{m}$. The possible reason for this difference is that the increase in the temperature rise in cases with downward airflow enhances the thermophoretic force, which leads to an increase in smaller particle deposition. Although the average air velocity in cases with sideward airflow is larger than that in cases with downward airflow, this discrepancy of the decay rate loss coefficients for 0.3 ,

(a)

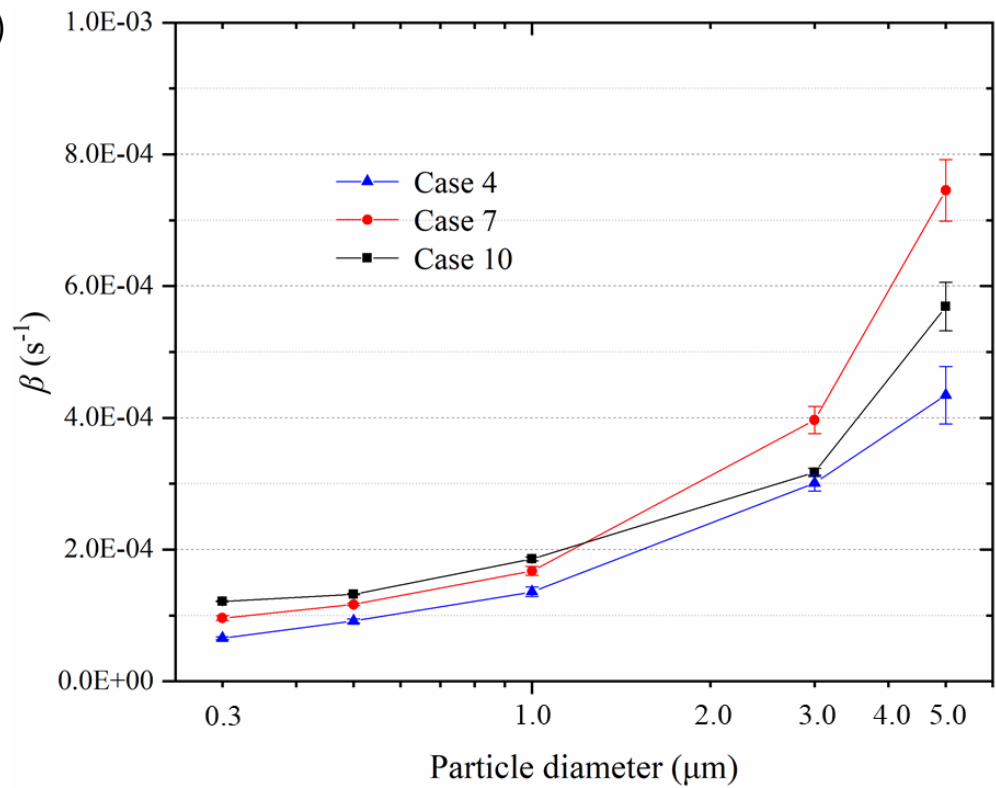

(b)

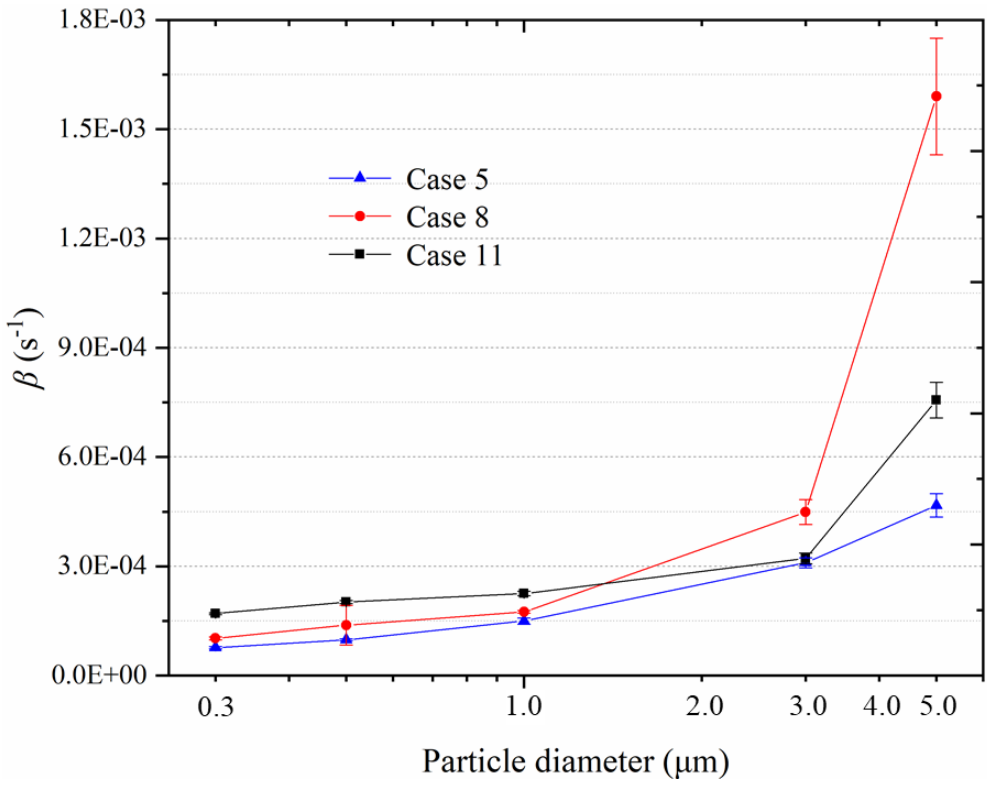

Fig. 5. Variation of particle decay rate loss coefficients with increasing particle diameters: (a) Cases 4, 7, and 10; (b) Cases 5, 8, and 11; and (c) Cases 6, 9, and 12. 
(c)

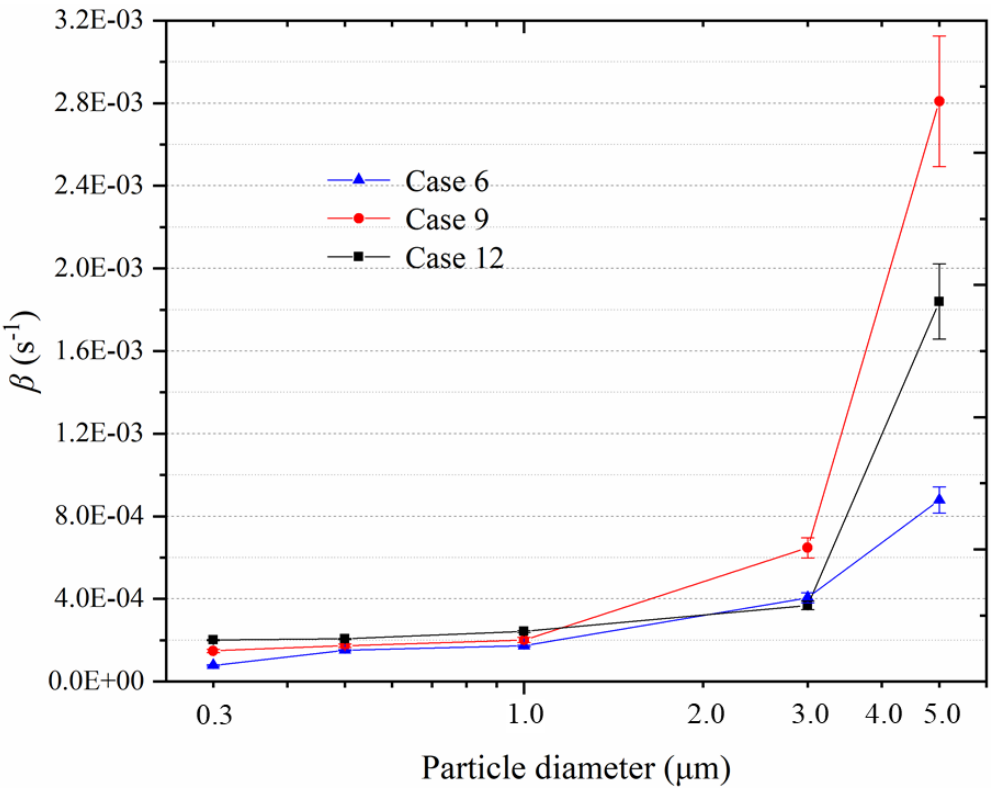

Fig. 5. (continued).

0.5 , and $1.0 \mu \mathrm{m}$ in these two air outlet orientations is observed. This finding may prove that the thermophoretic force exhibits greater effects than the airflow on smaller particles in this experiment. However, the decay rate loss coefficients in cases with downward airflow are significantly lower than that in cases with sideward airflow for larger particles (3.0 and $5.0 \mu \mathrm{m}$ ). The airflow likely plays a more important role than the thermophoretic force in the deposition of larger particles.

\subsection{Effect of the Distance between the Warm Air Heater and the Sampling Point}

Fig. 6 depicts the comparison of the particle decay rate loss coefficients at Sampling Points IIIV with different distances from the air outlet of the warm air heater. From the given graphs, it can be noticed that the particle decay rate loss coefficients at Sampling Point II are highest when keeping other parameters constant, followed by Sampling Point III, with Sampling Point IV lowest.

This well confirms that the region near the air outlet will be influenced by the warm air heater more seriously and the warm air heater contributes to the particle deposition near the air outlet. Results also reveal that the discrepancy between the particle decay rate loss coefficients at Sampling Points II and III in cases with the sideward airflow is the highest among those in the cases with different air outlet orientations, especially for $5.0 \mu \mathrm{m}$ particles. This result may be attributable to the greater difference between the air velocities in Cases 8 and 15. From Fig. 6, if other parameters are held constant, the difference between the particle decay rate loss coefficients at Sampling Points III and IV in cases with the upward and sideward airflows is observed to be lower than that in cases with the downward airflow. The cause may be ascribed to the larger gap between the temperature rises in Cases 17 and 18, which makes the distinction of effects of thermophoresis greater. Moreover, as it is seen in Fig. 6 and Table 2, the data imply that the warm air heater influences the particle, air velocity, temperature and relative humidity near the air outlet with various degrees.

In this paper, the effect of the heating power, air blowing direction, distance from the air outlet, humidifier, average air velocity, temperature rise, and relative humidity on particles in the indoor environment with a warm air heater is primarily investigated. A more in-depth discussion of the influence of some factors, such as the temperature rise, relative humidity drop and average air velocity, on indoor particles can be considered in future studies. Moreover, in the consequent research, it is expected to extend the experimental scope by considering the effect of some other factors such as human activity on particle dispersion and deposition, and thus providing more comprehensive researches. Another recommendation for future study is that an analysis of the synergistic effects of influencing factors is conducted and the most significant factor in the 


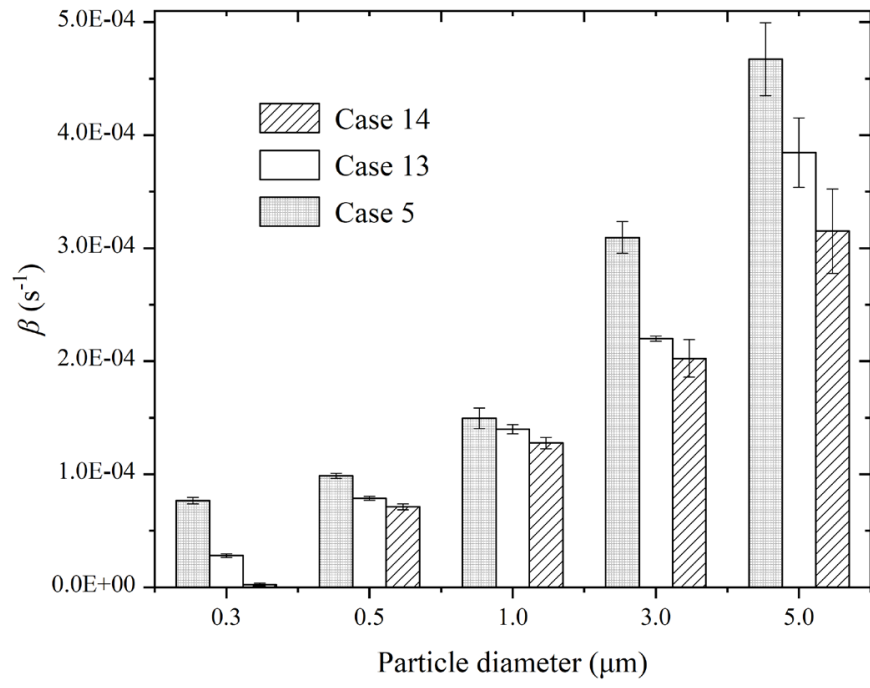

(a)

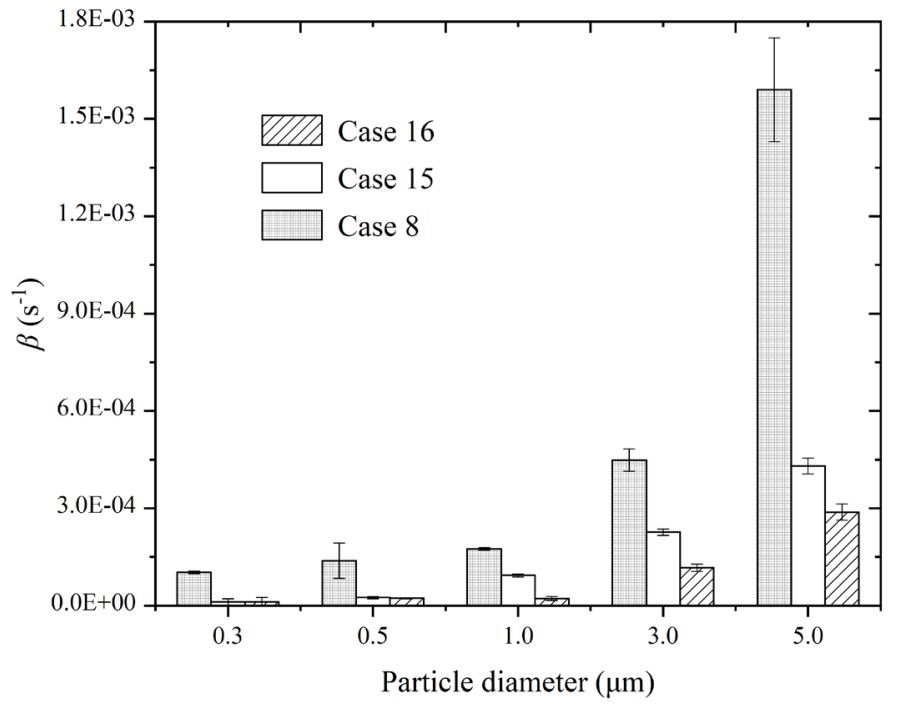

(b)

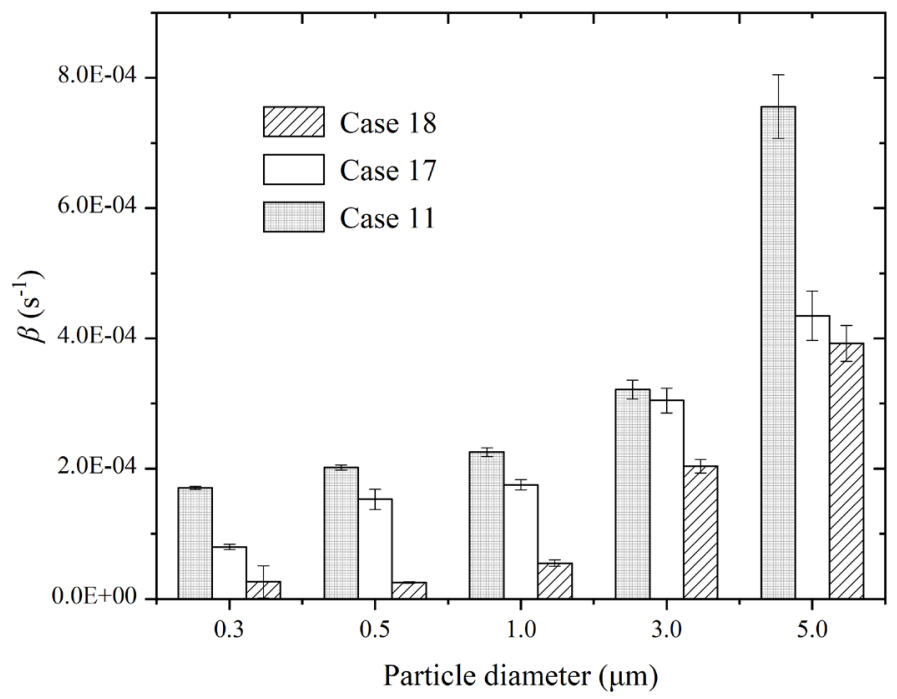

(c)

Fig. 6. Effect of the distance between the warm air heater and the sampling point on the particle decay rate loss coefficients: (a) Cases 5, 13, and 14; (b) Cases 8, 15, and 16; and (c) Cases 11, 17, and 18.

particle dispersion and deposition should be probed. In addition, it is necessary to carry out further exploration on building a connection between the experimental settings and the real situation and providing the scientific basis for improving the indoor air quality during the heating period.

\section{CONCLUSIONS}

In this study, we measured the particle concentrations, air velocities, temperature, and relative humidity in a storeroom equipped with a warm air heater. We also evaluated the effects of the heater on the dispersion and deposition of particles ranging in diameter from 0.3 to $5.0 \mu \mathrm{m}$ in 18 case scenarios. Our main findings are as follows:

1) The particles exhibited higher deposition rates when the warm air heater was operational than when it was idle.

2) Using a humidifier (with tap water) inside the storeroom in addition to the heater increased the particle concentrations.

3) When the heater was operational, larger particles deposited more quickly than smaller ones near the air outlet. 
4) The rates of decrease in the dimensionless concentrations of the particles, especially the smaller ones, increased with the output power of the heater.

5) The majority of the particle size fractions exhibited their lowest decay rate loss coefficients with an upward air flow. However, the $0.3,0.5$, and $1.0 \mu \mathrm{m}$ particles displayed higher coefficients with a downward than a sideward air flow, whereas the 3.0 and $5.0 \mu \mathrm{m}$ particles displayed higher coefficients with a sideward than a downward air flow.

6) The decay rate loss coefficients of the particles decreased as the distance from the air outlet of the heater increased.

\section{ACKNOWLEDGMENTS}

This work was supported by the National Natural Science Foundation of China (No. 51708180), the Youth Backbone Teacher Training Program of Henan University of Technology (No. 21420099), and the Research Funds of Key Laboratory of Heating and Air Conditioning, Education Department of Henan Province (No. 2016HAC102).

\section{REFERENCES}

Cao, S.J., Kong, X., Li, L., Zhang, W., Ye, Z., Deng, Y. (2017). An investigation of the $\mathrm{PM}_{2.5}$ and $\mathrm{NO}_{2}$ concentrations and their human health impacts in the metro subway system of Suzhou, China. Environ. Sci. Process. Impacts 19, 666-675. https://doi.org/10.1039/C6EM00655H

Chaivisit, P., Fontana, A., Galindo, S., Strub, C., Choosong, T., Kantachote, D., Suksaroj, T.T. (2018). Airborne bacteria and fungi distribution characteristics in natural ventilation system of a university hospital in Tailand. Environ. Asia 11, 53-66. https://doi.org/10.2486/indhealth.48.236

Chen, X., Li, A. (2014). An experimental study on particle deposition above near-wall heat source. Build. Environ. 81, 139-149. https://doi.org/10.1016/j.buildenv.2014.06.020

Chen, X., Li, A. (2015). Particle size distributions and concentrations above radiators in indoor environments: Exploratory results from Xi'an, China. Environ. Eng. Res. 20, 237-245. https://doi.org/10.4491/eer.2015.057

Cheng, Y., Yan, L., Huang, Y., Wang, Q., Morawska, L., Gu, Z., Cao, J., Zhang, L., Li, B., Wang, Y. (2019). Characterization of particle size distributions during winter haze episodes in urban air. Atmos. Res. 228, 55-67. https://doi.org/10.1016/j.atmosres.2019.04.033

Dehghan, M.H., Abdolzadeh, M. (2018). Comparison study on air flow and particle dispersion in a typical room with floor, skirt boarding, and radiator heating systems. Build. Environ. 133, 161-177. https://doi.org/10.1016/j.buildenv.2018.02.018

Dong, Z., Su, F., Zhang, Z., Wang, S. (2020). Observation of chemical components of $\mathrm{PM}_{2.5}$ and secondary inorganic aerosol formation during haze and sandy haze days in Zhengzhou, China. J. Environ. Sci. 88, 316-325. https://doi.org/10.1016/j.jes.2019.09.016

Dunn, K.L., Dunn, K.H., Hammond, D., Lo, S. (2020). Three-dimensional printer emissions and employee exposures to ultrafine particles during the printing of thermoplastic filaments containing carbon nanotubes or carbon nanofibers. J. Nanopart. Res. 22, 46. https://doi.org/1 0.1007/s11051-020-4750-8

Fang, Y., Naik, V., Horowitz, L.W., Mauzerall, D.L. (2013). Air pollution and associated human mortality: The role of air pollutant emissions, climate change and methane concentration increases from the preindustrial period to present. Atmos. Chem. Phys. 13, 1377-1394. https://doi.org/10.5194/acp-13-1377-2013

Feng, Z., Zhou, X., Xu, S., Ding, J., Cao, S.J. (2018). Impacts of humidification process on indoor thermal comfort and air quality using portable ultrasonic humidifier. Build. Environ. 133, 62-72. https://doi.org/10.1016/j.buildenv.2018.02.011

Frasca, D., Marcoccia, M., Tofful, L., Simonetti, G., Perrino, C., Canepari, S. (2018). Influence of advanced wood-fired appliances for residential heating on indoor air quality. Chemosphere 211, 62-71. https://doi.org/10.1016/j.chemosphere.2018.07.102

Golkarfard, V., Talebizadeh, P. (2014). Numerical comparison of airborne particles deposition and dispersion in radiator and floor heating systems. Adv. Powder Technol. 25, 389-397. https://doi.org/10.1016/j.apt.2013.06.008 
Hasan, M.R., Hossain, M.A., Sarjana, U., Hasan, M.R. (2016). Status of air quality and survey of particulate matter pollution in Pabna city, Bangladesh. Am. J. Eng. Res. 5, 18-22.

Jin, S., Ma, Y., Zhang, M., Gong, W., Lei, L., Ma, X. (2019). Comparation of aerosol optical properties and associated radiative effects of air pollution events between summer and winter: A case study in January and July 2014 over Wuhan, Central China. Atmos. Environ. 218, 117004. https://doi.org/10.1016/j.atmosenv.2019.117004

Kim, K.H., Kabir, E., Kabir, S. (2015). A review on the human health impact of airborne particulate matter. Environ. Int. 74, 136-143. https://doi.org/10.1016/j.envint.2014.10.005

Li, J., Du, H., Wang, Z., Sun, Y., Yang, W., Li, J., Tang, X., Fu, P. (2017). Rapid formation of a severe regional winter haze episode over a megacity cluster on the North China Plain. Environ. Pollut. 223, 605-615. https://doi.org/10.1016/j.envpol.2017.01.063

Liu, C., Chen, R., Sera, F., Vicedo-Cabrera, A.M., Guo, Y., Tong, S., Coelho, M.S.Z.S., Saldiva, P.H.N., Lavigne, E., Matus, P., Valdes Ortega, N., Osorio Garcia, S., Pascal, M., Stafoggia, M., Scortichini, M., Hashizume, M., Honda, Y., Hurtado-Díaz, M., Cruz, J., ..., Kan, H. (2019). Ambient particulate air pollution and daily mortality in 652 Cities. N. Engl. J. Med. 381, 705-715. https://doi.org/ 10.1056/NEJMoa1817364

Meišutovič-Akhtarieva, M., Prasauskas, T., Čiužas, D., Krugly, E., Keraitytė, K., Martuzevičius, D., Kaunelienè, V. (2019). Impacts of exhaled aerosol from the usage of the tobacco heating system to indoor air quality: A chamber study. Chemosphere 223, 474-482. https://doi.org/10. 1016/j.chemosphere.2019.02.095

Moriske, H.J., Drews, M., Ebert, G., Menk, G., Scheller, C., Schöndube, M., Konieczny, L. (1996). Indoor air pollution by different heating systems: Coal burning, open fireplace and central heating. Toxicol. Lett. 88, 349-354. https://doi.org/10.1016/0378-4274(96)03760-5

Ozgen, S., Ripamonti, G., Cernuschi, S., Giugliano, M. (2012). Ultrafine particle emissions for municipal waste-to-energy plants and residential heating boilers. Rev. Environ. Sci. Biotechnol. 11, 407-415. https://doi.org/10.1007/s11157-012-9280-0

Qin, K., Wang, L., Wu, L., Xu, J., Rao, L., Letu, H., Shi, T., Wang, R. (2017). A campaign for investigating aerosol optical properties during winter hazes over Shijiazhuang, China. Atmos. Res. 198, 113-122. https://doi.org/10.1016/j.atmosres.2017.08.018

Robinson, J., Nelson, W.C. (1995). National Human Activity Pattern Survey Data Base. U.S. EPA, Research Triangle Park, NC.

Seduikyte, L., Stasiuliene, L., Prasauskas, T., Martuzevičius, D., Černeckienė, J., Ždankus, T., Dobravalskis, M., Fokaides, P. (2019). Field Measurements and numerical simulation for the definition of the thermal stratification and ventilation performance in a mechanically ventilated sports hall. Energies 12, 2243. https://doi.org/10.3390/en12122243

Shao, P., Tian, H., Sun, Y., Liu, H., Wu, B., Liu, S., Liu, X., Wu, Y., Liang, W., Wang, Y., Gao, J., Xue, Y., Bai, X., Liu, W., Lin, S., Hu, G. (2018). Characterizing remarkable changes of severe haze events and chemical compositions in multi-size airborne particles $\left(\mathrm{PM}_{1}, \mathrm{PM}_{2.5}\right.$ and $\left.\mathrm{PM}_{10}\right)$ from January 2013 to 2016-2017 winter in Beijing, China. Atmos. Environ. 189, 133-144. https://doi.org/10.1016/j.atmosenv.2018.06.038

Silberstein, S. (1979). Heating system-generated indoor air pollution. Energy Build. 2, 271-278. https://doi.org/10.1016/0378-7788(79)90038-0

Spolnik, Z., Worobiec, A., Samek, L., Bencs, L., Belikov, K., Van Grieken, R. (2007). Influence of different types of heating systems on particulate air pollutant deposition: The case of churches situated in a cold climate. J. Cult. Herit. 8, 7-12. https://doi.org/10.1016/j.culher.2006.09.003

Stabile, L., Buonanno, G., Avino, P., Frattolillo, A., Guerriero, E. (2018). Indoor exposure to particles emitted by biomass-burning heating systems and evaluation of dose and lung cancer risk received by population. Environ. Pollut. 235, 65-73. https://doi.org/10.1016/j.envpol.2017.12.055

Wang, Y., Fan, X., Li, A., Shang, L., Wang, H. (2018). Deposition of fine particles on vertical textile surfaces: A small-scale chamber study. Build. Environ. 135, 308-317. https://doi.org/10.1016/ j.buildenv.2018.03.003

Weichenthal, S., Dufresne, A., Infante-rivard, C., Joseph, L. (2007). Indoor ultrafine particle exposures and home heating systems: A cross-sectional survey of Canadian homes during the winter months. J. Exposure Sci. Environ. Epidemiol. 17, 288-297. https://doi.org/10.1038/sj.je s.7500534

Xiong, Q.L., Zhao, W.J., Gong, Z.N., Zhao, W.H., Tang, T. (2015). Fine particulate matter pollution 
and hospital admissions for respiratory diseases in Beijing, China. Int. J. Environ. Res. Public Health 12, 11880-11892. https://doi.org/10.3390/ijerph120911880

Xu, C., Wei, M., Chen, J., Wang, X., Zhu, C., Li, J., Zheng, L., Sui, G., Li, W., Wang, W., Zhang, Q., Mellouki, A. (2017). Bacterial characterization in ambient submicron particles during severe haze episodes at Ji'nan, China. Sci. Total Environ. 580, 188-196. https://doi.org/10.1016/j.scito tenv.2016.11.145

Yang, S., Ma, Y.L., Duan, F.K., He, K.B., Wang, L.T., Wei, Z., Zhu, L.D., Ma, T., Li, H., Ye, S.Q. (2018). Characteristics and formation of typical winter haze in Handan, one of the most polluted cities in China. Sci. Total Environ. 613-614, 1367-1375. https://doi.org/10.1016/j.scitotenv.2017.08.033

Ye, S., Ma, T., Duan, F., Li, H., He, K., Xia, J., Yang, S., Zhu, L., Ma, Y., Huang, T., and Kimoto, T. (2019). Characteristics and formation mechanisms of winter haze in Changzhou, a highly polluted industrial city in the Yangtze River Delta, China. Environ. Pollut. 253, 377-383. https://doi.org/10.1016/j.envpol.2019.07.011

Zhao, Z.Z. (2014). Study on the Pollution Characteristics and Dynamic Changes of Particulate Matter in an Office Environment. Master thesis. North China Electric Power University. (In Chinese) https://kns.cnki.net/kcms/detail/detail.aspx?dbcode=CMFD\&dbname=CMFD20170 1\&filename $=1016276556$. nh\&v=PLD3L0jwNivsP47oPtP3AWvrjwTH2n4Gb2Bo2XssmCAUQKT oB2pPUiMOTgQWrPOx

Zhou, Y., Deng, Y., Wu, P., Cao, S.J. (2017). The effects of ventilation and floor heating systems on the dispersion and deposition of fine particles in an enclosed environment. Build. Environ. 125, 192-205. https://doi.org/10.1016/j.buildenv.2017.08.049 